\title{
Calling for a Plurality of Perspectives on Design Futuring: An Un-Manifesto
}

\author{
Noura Howell \\ North Carolina State University, U.S. \\ noura.howell@gmail.com
}

Rocío Fatás Arana

Srishti-Manipal Institute of Art,

Design and Technology, India

rociofatas@srishti.ac.in

\author{
Britta F. Schulte \\ Bauhaus-University Weimar, \\ Germany \\ britta.schulte@uni-weimar.de \\ Sumita Sharma \\ INTERACT Research Unit, University \\ of Oulu, Finland \\ sumita.sharma@oulu.fi
}

\author{
Amy Twigger Holroyd \\ Nottingham Trent University, U.K. \\ amy-twigger.holroyd@ntu.ac.uk
}

\author{
Grace Eden \\ Department of Human-Centred \\ Design Indraprastha Institute of \\ Information Technology, Delhi (IIITD) \\ India,grace@iiitd.ac.in
}

\begin{abstract}
The Futures Cone, a prominent model in design futuring, is useful for promoting discussions about possible, plausible, probable, and preferable futures. Yet this model has limitations, such as representing diverse human experiences as a singular point of "the present" and implicitly embedding notions of linear progress. Responding to this, we argue that a plurality of perspectives is needed to engage imaginations that depict a diverse unfolding of potential futures. Through reflecting on our own cultural and professional backgrounds, we offer five perspectives for design futuring as a contribution to this plurality: Parallel Presents, "I Am Time", Epithelial Metaphors, the Uncertainties Cone, and Meet (with) "Speculation". These perspectives open alternative approaches to design futuring, move outside prevalent notions of technological progress, and foreground interdependent, relational agencies.
\end{abstract}

\section{CCS CONCEPTS}

- Human-centered computing $\rightarrow$ Human computer interaction (HCI); HCI theory, concepts and models.

\section{KEYWORDS}

design futuring, speculative design, discursive design, plurality, un-manifesto

\section{ACM Reference Format:}

Noura Howell, Britta F. Schulte, Amy Twigger Holroyd, Rocío Fatás Arana, Sumita Sharma, and Grace Eden. 2021. Calling for a Plurality of Perspectives on Design Futuring: An Un-Manifesto. In CHI Conference on Human Factors in Computing Systems Extended Abstracts (CHI '21 Extended Abstracts), May 08-13, 2021, Yokohama, Japan. ACM, New York, NY, USA, 10 pages. https: //doi.org/10.1145/3411763.3450364

Permission to make digital or hard copies of part or all of this work for personal or classroom use is granted without fee provided that copies are not made or distributed for profit or commercial advantage and that copies bear this notice and the full citation on the first page. Copyrights for third-party components of this work must be honored For all other uses, contact the owner/author(s).

CHI '21 Extended Abstracts, May 08-13, 2021, Yokohama, Japan

(c) 2021 Copyright held by the owner/author(s).

ACM ISBN 978-1-4503-8095-9/21/05.

https://doi.org/10.1145/3411763.3450364

\section{INTRODUCTION}

The Futures Cone $[24,96,107]$ is a prominent model in design futuring. We (co-authors) have used the Futures Cone to introduce design futuring to students and appreciate its utility in opening up a narrow view of the future into multiple possibilities. However, when we came together to discuss participatory approaches to design futuring, we identified problems with the model's embedded assumptions around linear time and "progress". We asked, how might design futuring engage other conceptions of time, futuring, and human agency?

We sought to imagine a plurality of perspectives for approaching design futuring; we offer five perspectives on design futuring that conceptualize time and futuring differently: Parallel Presents invites speculation on contemporary realities in fictional worlds that split off from our own at key historical junctures; "I Am Time" offers a spiritual approach to cyclical time, inspired by an Indian TV show narrator's proclamation [114]; Epithelial Metaphors frames change in terms of complex organic transformations, in an ambiguous gesture characteristic of artistic practice; the Uncertainties Cone invites humility and embracing uncertainty, inspired by the expressions insha'Allah (Arabic) and ojalá (Spanish); and Meet (with) "Speculation" questions the binary between present and future and asks people to reflect on their positionality and values they bring into their futures. For each perspective, we introduce the cultural background that inspires it, explain how it (re)frames time, walk through applying it to an example design futuring project, and reflect on its potential and limitations.

In the following section, we introduce the Futures Cone and discuss its limitations. Then, we describe the reflective process by which we articulated alternative perspectives for design futuring, drawing from our diverse personal and professional backgrounds. Next, we describe each perspective. Finally, we discuss how different perspectives offer different reorientations toward time and designerly agency. These perspectives on design futuring are not intended to be portable models ready for universal uptake; rather we call them perspectives to emphasize their partiality and situatedness. Our perspectives sometimes contradict, and they do not form a "complete" set. By offering a few of our own perspectives on design futuring, we invite others to share their own perspectives and thus continue to diversify assumptions, worldviews, and approaches for design futuring. 


\section{BACKGROUND \& MOTIVATION}

Design research has increasingly focused on imagining and debating alternative futures through methods such as speculative design [24], discursive design [95], and design fiction (e.g., [19, 52, 63, 92]). Following Kozubaev et al., we use design futuring as an umbrella term to loosely refer to such approaches, which are "concerned with future alternatives" and which seek to "produce knowledge through debate, contestation, reflection etc.” (p.2) [53].

The Futures Cone (Fig. 1) is widely used in design futuring. It frames future possibilities via four cones: possible, plausible, probable, and preferable [96]. Used by Voros [96] and adapted for Dunne \& Raby's Speculative Everything [24], it is used in design education and even spotted as graffiti [79]. Though valuable in opening discussion about projected futures, the Futures Cone embeds assumptions: Time is framed as progressing linearly. The present is depicted as a single dot, risking flattening a multitude of diverse lived experiences. The past is dangerously absent from the model, given that history provides "the building blocks from which the future is made" (p.1) [11] Whose present point is represented? Whose preferable futures are imagined?

We follow Mazé's call to critically engage assumptions at work in design futuring, including linear time, modernity, progress, tripartite past/present/future, and issues of race and gender [60]. Wong and Khovanskaya outline speculative design's historically close relationship with corporate innovation practice, and invite speculative design researchers to more closely attend to the criticality of the questions posed and audiences engaged via speculative design [110]. Selkirk et al. call for troubling futuring to explore alternative modes of knowing the future, opening to many possibilities in a "festival of futures" [85]. Chatterton and Newmarch engage Gibson's phrase, "The future is already here, it's just not very evenly distributed," to call for not re-inscribing present and historical inequalities into future visions [15]. We also attend to realities that differ from typical imaginaries of techno-progress (e.g., [109]). Drawing from Tunstall's argument that diversity and inclusion are insufficient for decolonizing design education [76, 101-103], we argue design futuring needs not only more diverse practitioners but also to continue opening to diverse approaches and perspectives. We seek to bring design futuring practices closer to Escobar's notion of the pluriverse, in which many futures can exist, informed by local histories and centering relationality over individualist modernity [25].

Prior work has adapted the Futures Cone: Lindley et al. [57] draw from Coulton's [18] double cone that faces "forward" and "backward" in time, depicted in an individual's mind to emphasize the importance of individual interpretation. Holbert et al. add to the Futures Cone by charting "a cycle of connecting back to personal and communal histories and reflecting forward on current and local systems" (p.332) [43]. Candy and Watson's card game [98] facilitates imagining future scenarios of growth, collapse, discipline, and transformation via particular artifacts, drawing from The Manoa School's scenarios [20]. Ushigome and collaborators superimpose many dual past/present cones to represent different locations, cultures, and futures [39]. Our work complements these efforts for more situated, cultural, aesthetic, and philosophical approaches to

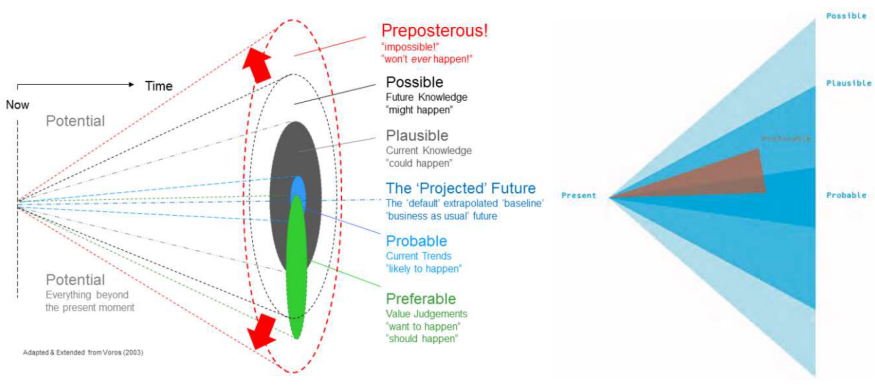

Figure 1: Futures Cone by $\odot$ Voros [96] (left) and $\odot$ Dunne and Raby [24] (right).

design futuring. Instead of readily transferable models, our perspectives offer more explicitly partial and situated approaches.

These alternative approaches invite consideration of deeper questions around design futuring and temporality. O'Leary et al. ask, "Who gets to future?" and offer critical reflections on how "conventional design practices may perpetuate forms of institutional racism" (p.1) [100]. They suggest that design futuring may offer "a way for community members to collectively imagine" (p. 10) [100] via "a process of finding a suitable future by framing a suitable past” (p.10) [100]. Holbert et al. reflect on personal and community histories for Afrofuturist design futuring [43]. Puig de la Bellacasa argues for a focus on "care time" and "a diversity of timelines that, despite being made invisible or marginalized in the dominant timescape, can challenge traditional notions of technoscientific innovation" (p.692) [74]. Our international tri-continental collaboration began with a keen interest in approaches that engage diverse groups with design futuring. The perspectives we offer draw from our own personal and cultural histories as one small step toward greater plurality in design futuring and "genuinely open futures" of divergent imaginations [25].

\section{PROCESS}

This project began in a workshop, "Speculative and Critical Design in Education: Practice and Perspectives” [40]. Afterward, a sub-group initiated follow up meetings, initially inspired by the question of how to engage people who are not designers in speculative activities. Our work engages participants such as children, fashion specialists and engineering students-who may be new to design methods and speculation. We reflected on the responsibility that we feel towards those whom we inspire to speculate and a dissatisfaction with some of the methods available to us. With participants joining from India, the US and Europe, we discussed what we mean by "speculation" and "the future" itself. We engaged in a reflective process drawing from our own personal, cultural and professional backgrounds and approaches to design futuring. In group discussions we each developed a sketch of a personally relevant approach to design futuring. Although we each individually developed one perspective, the perspectives informed one another as we asked each other probing questions to develop the perspectives, expanding beyond an individual meaning to articulate how each might be understood by others. The results of this process are the five perspectives. 
We refer to this collection of perspectives as an un-manifesto to signify their diversity and the contradictions between them. While we draw on the urgency and call to action of other manifestos $[35,47,58,59]$, we choose not to commit to a unified set of claims, but rather to highlight a plurality of perspectives for design futuring. Our un-manifesto invites others to create diverse approaches to speculation and open up the process of futuring. In the interest of bringing diverse people and cultural ways of knowing to bear on design futuring, we interweave our positionalities throughout the perspectives. Taken together, our perspectives are highly varied but certainly still partial and privileged. They offer an outlook toward greater plurality for design futuring, working in tandem with other efforts for participation, inclusion, sustainability, and responsibility (e.g., [7, 33, 44, 48, 51, 53, 75, 81-83, 87-90, 104-106, 108]) and indebted to efforts for design justice (e.g., $[4,5,17,23,64,76,101-$ 103]).

\section{PERSPECTIVES}

Here we offer five perspectives on design futuring. For each, we provide background, suggestions for use, an example, and reflection on its potential and limitations.

\subsection{Parallel Presents}

Parallel Presents is an approach for speculating that does not project into the future, but rather explores contemporary realitiespresents-in fictional parallel worlds. These fictional worlds stem from our own through a shared history: a key event, or juncture, in the past has caused the fictional world to split from our world, with the alternative outcome of this event initiating a separate forward path. This perspective guides participants to imagine preferred presents, and then create engaging backstories for those imagined worlds (Fig. 2). The juncture could be a factual event, such as a war, election or something more mundane; equally, it could be entirely fictional.

Background: This perspective is informed by the counterfactual approach to speculation used extensively in literature and, to a more limited extent, in design futuring. Dunne and Raby [24] discuss this approach to speculation: "A historical fact is changed to see what might have happened, if ...”. For example, a novel explores an alternate world in which Germany and Japan won WWII [22] or another novel wherein, several centuries ago, Africans colonised Europe [13]. Parallel Presents turns the conventional counterfactual process upside down. Rather than identifying a historical juncture and considering possible alternative paths forward, this methodwhich loosely corresponds with Bendor et al.'s hypothetical notion of "pastcasting" [11]-imagines a preferred world and then works back to an invented juncture. The approach encourages the development of a multiplicity of parallel worlds, rather than a single fiction, inspired by children's literature of Diana Wynne Jones [72].

Use: First, select an issue to be interrogated. Construct an engaging idea for a preferred alternative present: a world like our own, but with key differences in its practices and cultures. Next, imagine the historical path that could have led to this present, identifying or inventing an appropriate juncture that initiated its development, such as a natural disaster or the emergence of an influential cultural movement. By repeating this entire process, a

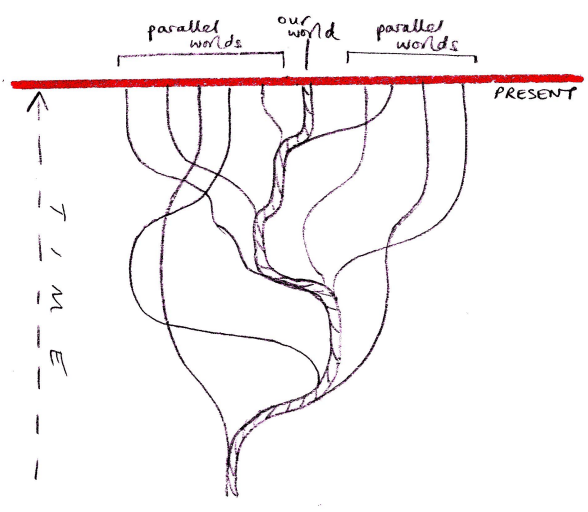

Figure 2: The horizontal line indicates the present, with the main vertical strand representing the history of our world. The offshoots represent invented paths between historical junctures and fictional parallel worlds.

range of worlds can be created to investigate an area of interest from multiple perspectives.

Example: Amy, a British fashion design researcher, currently uses the Parallel Presents perspective in her Fashion Fictions ${ }^{1}$ project, which brings people together to explore fictional visions of alternative fashion cultures and systems. Participants are invited to identify a problematic issue in the fashion sector, such as rapid disposal of clothing or lack of inclusivity in fashion media, and to describe an alternative scenario and backstory. An interactive "Fashion Fictions generator" ${ }^{2}$ provides a playful means of exploring starting points for these worlds, with multiple options within four variable fields offering over 20,000 possible combinations. For example (variable fields in italics): "In World X, shared community wardrobes can be found in countries across the world. The origins of this culture can be traced back to $a$ groundswell of grassroots activity in 2010." Or: "In World X, a unisex jumpsuit is the default clothing option in one ostensibly sleepy village. The origins of this culture can be traced back to a cult text written in 1923."

Potential \& Limitations: As Auger [6] explains, parallel world fictions re-imagine the present day, questioning cultural, political and technological norms in a particular society or community. This perspective is therefore well suited to projects that seek to interrogate alternatives to contemporary systems, rather than projections of how we may, or may not, wish our contemporary systems to develop. For example, it can be used to consider the role and status of technologies within our speculative explorations. It opens up possibilities for imagining worlds that challenge notions of progress by using more basic technologies than those that are prevalent in our contemporary world, for focusing on social norms and cultural practices rather than emerging technologies, and for respectfully learning from cultures that have been marginalised by technocentric modernity.

\footnotetext{
${ }^{1}$ http://fashionfictions.org/

${ }^{2}$ https://fashionfictions.github.io/generator/
} 


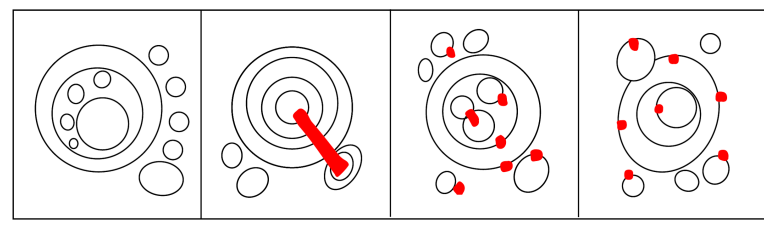

Figure 3: A series of cyclic times of individuals or groups of people who share a common experience (the red bar) that transforms or shapes their lives in different ways and at a different pace.

\section{2 "I Am Time"}

"I Am Time" shifts the focus of design futuring to consider how spiritual transformations embrace a cyclic, iterative process of change. The experience of time is deeply personal and spiritual. For a child the future is far, full of possibilities, a distant dream; for an adult, the future is just around the corner, or a place they might never get to see. This perspective also reminds us that each living entity has its own time, an internal rhythm of transformation-a baby as they grow, a bud as it blooms-and this rhythm is cyclic, passing through days and seasons, birth and death. Where is the future then? From this perspective, the future is spiritual yet collective and connected; we have some agency yet are also tossed, turned, tumble-drying in a cyclic process of change; personal yet shared; both an end and a start.

Background: Sumita, who grew up mostly in India, recalled the narrator of a great Sanskrit epic in TV series Mahabharata [114] proclaiming: "I am time. I am the past, the present, and the future". This omnipresent narrator was privy to events across time and place: a notion that feels spiritual and powerful. Drawing further on her cultural background, she observed that time is cyclic in Hinduism: from the cosmological time of the four yugas or epochs that repeat every 4,320,000 years [117], to the reincarnation of the soul, whose ultimate goal is to attain moksha, or enlightenment, and thus free itself from the cycle of birth and death. This cyclic aspect of time, or concept of reincarnation, is not individual to Hinduism but shared across various religions and communities, but Sumita was introduced to it within a Hindu household and took inspiration from that experience. From the perspective of design futuring then, time can be seen as an internal and spiritual rhythm of transformation, one that repeats (reincarnates) through familiar and shared experiences across cultures and age groups.

Use: Transformation at a spiritual and personal level: Designing for alternative futures means designing for deep transformational spiritual experiences, where an individual or group progress and transform or even regress and undo from a current state to another state of being and experience. How is this transformation supported or triggered? How are individual and community aspirations and future desires supported?

Use: Cyclic process of change: Moving from the human frame to other kinds of living beings and phenomena, time is also a cyclic process of change, e.g., sunrise and sunset, the seasons, the ageing sun. In each cycle, some changes might be predetermined, intentional, destined, yet others are influenced by individual or community transformations. When designing for alternative futures instead of linear progress, consider an iterative process of change: what happens in the nth cycle?

Example: From Sumita's diverse experiences researching with children and technology, from a typical Finnish classroom in Tampere to a community school in the Okhla slums in New Delhi [87], it was evident that techno-progress is a matter of when and not if. Even in underserved contexts, socio-technical aspirations for the future can motivate individuals and groups to accept, adopt and adapt new technologies [56, 69, 86, 99], where each individual experiences their own unique transformation; e.g., first-time access to the internet [3]. This perspective captures these individual transformations and aspirations that unfold across time differently and in different contexts, making design futuring inclusive and open to personal experiences representing diverse realities.

Potential \& Limitations: This approach is not meant for design futuring led by single designers or researchers. Instead of enhancing individual agency, it seeks to bring transformation, spirituality, and aspiration to the design futuring process. Instead of focussing on one group of people or one future, it fosters a progression of futures at an individual level and pace, where no one way is preferred over another. "I Am Time" urges researchers to consider individual or collective transformations for creating future designs and scenarios.

\subsection{Epithelial Metaphors}

This perspective employs a central metaphor of epithelial cells. These cover organs of the body forming specialised tissues by replicating and assembling themselves, exchanging nutrients in gap junctures. Similarly, epithelial futures form associations around themes, "combining" and "exchanging" bits of information. They spread in conceptual space rather than time, prioritizing relationality over linear progression. Drawing from the arts, artistic pedagogy, and arts writing (e.g., $[12,28,61,112,113,115])$, this perspective is intentionally ambiguous and obscure to stimulate the imagination beyond the purely logical. Thus we could conceive futures like cells build tissues.

Background: This approach embraces intuition and flat associative hierarchies [49], analyzing and combining many existing factors (Fig. 4). Criticality as "humanistic epistemology" and positionality for a "distinctive voice" [8] provide a double lens to filter and form associations. They form chance connections, a complex of systems interacting with each other [16] in a chaotic formation, a mash-up of destiny, luck and control. Epithelial webs of futures exist "across time, space and domains", to picture a "dynamic view of things that are constantly changing into other things" (p. 50) [16]. In this organic fabric, like in systems of divination, past, present and future lose their hierarchical linearity to gain equal structural importance. This perspective "thinks in fields" [27], following synchronistic rather than causal logics, associating concepts and events by meaning instead of succession.

Use: Explore a chosen subject by asking questions from angles that account for its past and culture, to generate insights. For example Anthropology (Fig. 4) may help articulate ancestral practices 


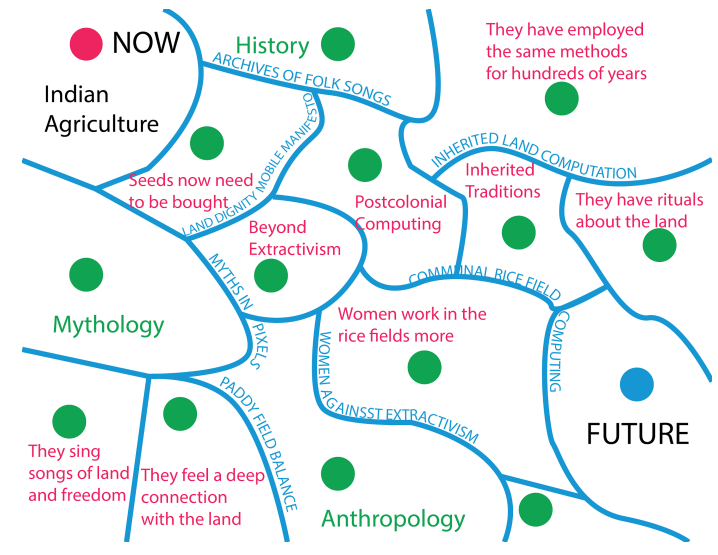

Figure 4: Green disciplines, red insights, and blue imagined futures form a conceptual plane in which present and future are yet two more conceptual components in the flat hierarchy.

of women cultivating the land. Questioning is the core of the process, as cell nuclei. The insights are as enzymes or particles in a system of moderate chaos. Pores act as a twofold filter of criticality and positionality; the theme is filtered through them as if looking through a lorgnette ${ }^{3}$. Autonomous futures ${ }^{4}$ are the secretion, connected and formed by narratives that are creative [49] yet binding, arranged in relation to each other as an expansive array and plural collection of scenes. The skin is the formation containing all these elements as a membrane or interwoven fabric of futures.

Example: Epithelial Metaphors stems from Rocío teaching a speculative design class, Beyond Extractivism [26]. Indian agriculture was the subject of one sub-group, a topic of concern for Indian society inextricably linked to history. Questioning from different angles (Fig. 4) brought forth insights about inherited traditions and rituals for the land, current economic conditions of buying seeds, soil deterioration, farmers' mistreatment by transnational corporations, and agricultural policies $[32,54,70]$. With the criticality of feminist $[9,10]$ and decolonial $[46,71,102]$ theories discussed in class, and the positionalities of students and professor working together across differences, students generated a variety of speculative designs [26]. Continuing to speculate, Rocío imagines autonomous futures such as Rural Women Against Extractivism, Land Dignity Mobile Manifesto, Myths in Pixels and Inherited Land Computation. These fictions form a complex epithelial surface linking past, present and future.

Potential \& Limitations: This perspective foregrounds realism and pluralism. To bind this seemingly chaotic set of insights, the design process requires selective criteria for synthesis, analysis and further development. This guides cells' positioning in relation to each other and logical tissue formation, visualising a map of

\footnotetext{
${ }^{3}$ The lorgnette (in Spanish 'impertinents'), became 'an indispensable accessory for the 19 th century lady about town' [97]. Originally they were mainly used by women, who did not normally wear glasses, often to observe and criticise. Here they are a wink to 'reading diffractively' [29].

${ }^{4}$ Escobar refers to autonomy as life 'from the inside' in use of 'autopoietic' organizational processes [25].
}

associative futures rather than a forward escapade from unpreferred realities. In this way it exemplifies interconnectedness as a parameter for resilience, similar to mangrove forests as examples of relational ontologies [25]. Epithelial futures are a metaphor for the small and the complex, comparing futures with the entangled nature of biological systems. This perspective might not be suitable for futures requiring technical precision. Instead, its strength lies in providing ample scope for creativity and associative reflection engaging with the Humanities, such as relating folk art to farming practices (Fig. 4). It enables exploring-and even insists on-the origin, embodiments and representational forms of concepts. It stresses imagination, and with criticality and positionality weakens naïveté. A broader advantage of this approach is inviting those from arts and arts writing backgrounds, drawing them into the liminal space of conceptual dreaming.

\subsection{The Uncertainties Cone}

The Uncertainties Cone offers a tactic to help design researchers stay humble, embrace uncertainty, and recognize interdependency. Its playfulness asks design researchers not to take themselves too seriously and to recognize limits of their own perception and agency.

Background: Noura reflected on using insha'Allah in spoken English with Arab family in the U.S. Insha'Allah means "if God is willing" and is often used in Arabic when expressing plans or hopes for the future; e.g., "I will come visit next year, insha'Allah". For Noura, this reminds her to stay humble and not take plans for granted. Responding to this, Rocío described ojalá in Spanish, also used to indicate uncertainty. The term stems from Muslim invasion of Spain centuries ago. Lacking religious meaning, ojalá can take on playful, hypothetical, or poetic connotations, inviting living from one moment to the next. We draw inspiration from these expressions while respectfully leaving their deeper meanings untouched. Drawing from event scores of Fluxus, HCI-Amusements, and Oliveros [21, 37, 38, 41, 42, 67, 68], this perspective presents simple text instructions to prompt embodied reflection.

\section{Use: The Uncertainties Cone Exercise:}

1. Roll paper into a cone leaving a small hole open at the tip. Fasten with tape.

2. Look through the small hole. Look around; move around. This represents the illusion of being able to clearly envision with the Futures Cone.

3. Look through the cone with the wide end around both eyes. Look around; move around. This represents the truth of existence, bumbling around with very limited awareness of what is at work around us.

4. Go to a corner, turn your back away from the room, and wear the cone as a dunce cap ${ }^{5}$. While in "time out", pause to reflect: (a) List factors that enable you to do design futuring, such as financial stability, institutional access, or activism shaping public awareness of an issue. (b) List risks that could hinder or derail the project, such as disease, environmental disaster, travel bans, or policy changes.

\footnotetext{
${ }^{5}$ Facing the corner wearing a dunce cap for 'time out' is a punishment for misbehaving children. While not advocating punishment, we playfully leverage the potential for halting destructive behavior and pausing to reflect.
} 


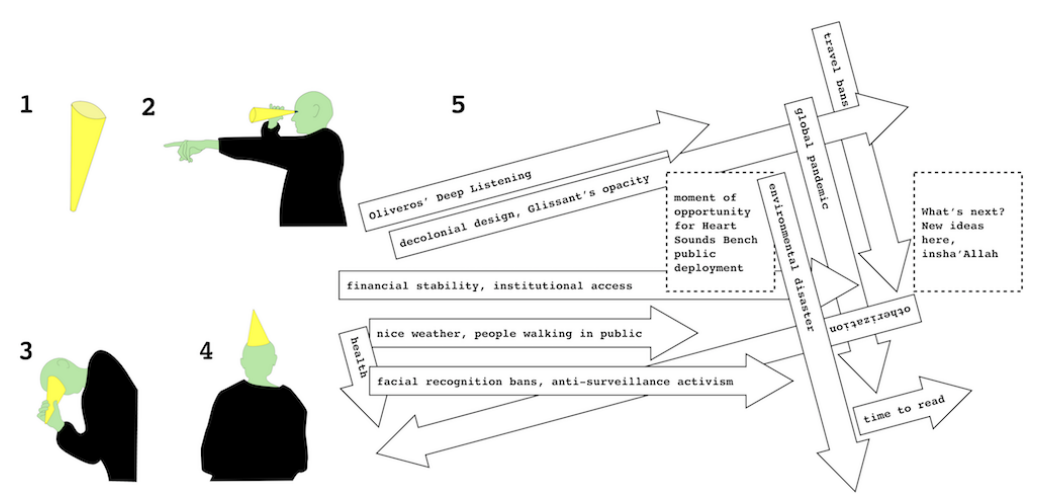

Figure 5: Steps 1-5 of the Uncertainties Cone Exercise. Step 5 is shown for an example project, the Heart Sounds Bench [45].

5. Return to a workspace. Write each factor on large paper arrows and cut them out. Arrange the arrows to chart the many forces at work beyond designerly agency. What do directions (e.g., right, up) indicate on your diagram?

6. Shrink those sweeping visions of the Futures Cone into tiny visionary steps. Acknowledge that every move is a leap of faith with unanticipated consequences. Make a move anyway, with humble close attention to what is not working and gratitude (rather than ownership or pride) for what is working.

Example: Fig. 5.5 illustrates results of Step 5 for the Heart Sounds Bench [45], a design futuring project in which heart sensors embedded in a public bench explore anti-surveillance visions. Arrows chart influences of many factors. Rightward indicates "forward" in time and upward indicates "beneficial" influences, but these axes can and should be reimagined in future playthroughs. The project is indebted to "anti-surveillance activism" (e.g., [14, 31, 65, 73, 77, 94]) and "Oliveros' Deep Listening” [66, 67]. "Otherization" is a far-reaching problem, yet its arrow is oriented as a slight upward ramp because the project's motivation is resisting otherization and turning it on its head. "Decolonial design" in HCI (e.g., [46, 64, 71]), and "Glissant's opacity" [30] guide resisting otherization. "Financial stability" and "institutional access" to equipment enabled particular forms of making. These factors made a space of opportunity for public deployment. Yet, factors presented roadblocks: illness, seasonal wildfires, and COVID-19. Overall, the exercise serves as a reminder not to overestimate designerly foresight and agency.

Potential \& Limitations: This perspective asks design researchers to stay humble and gratefully embrace uncertainty. It puts a sharp check on the projective ability of the Futures Cone, turning it backwards (Step 3) and upside down (Step 4). This perspective foregrounds interdependencies and vulnerabilities. Its playfulness asks design researchers not to take themselves too seriously, but rather to accept limits of their own perception.

\subsection{Meet (with) "Speculation"}

"Speculation" personifies the act of speculating and reminds us to be aware that the futures we invent affect the present. Deliberately ambiguous and androgenous, they play with (gender) queerness

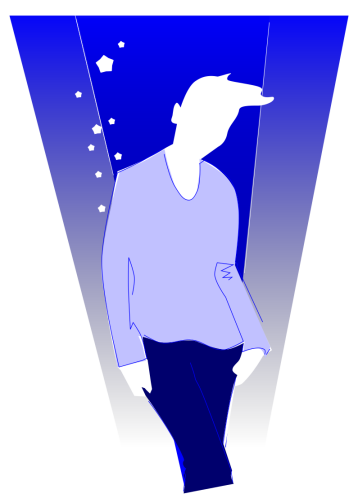

Figure 6: "Speculation", a personification of the act of speculation and a reminder that futures/presents are not binary.

and stand outside the binary of present/future, as these are linked without a specific beginning or end at either side. Therefore, rather than talking about "the future" one has to acknowledge the presence of futures, all of which are based in our present. Recognizing that futures are "unstable, fluidic fictions that are effects of regimes of power/knowledge..." (p.87) [50], they urge us to notice what we take for granted when futuring and to consider greater fluidity. As "queer time" [62] reminds us, not everyone walks with the same goals, aspirations, and timeframes.

Background: This perspective draws on queer theory, which, while recognizing that the term is not uncontested, is redefined as "a philosophical commitment to contesting the logics of normativity" [78]. Building on previous work in HCI [93], queering as a practice has potential to make research, design and futures more inclusive and diverse. In the context of design futuring, this involves reflecting on and challenging present norms when thinking about the future: heteronormativity and binary genders come to mind first, but this can be extended to other issues of class, race and age. Furthermore, speculative futures have an impact in the present as they tell others what we are willing to change-and what we are not. This perspective also owes a debt to Neil Gaiman's magical realism: "Speculation" aspires to be one of the Seven Endless from the Sandman comics [116]. 
Use: Queering the future means accepting the future itself as something that is fluid and connected to our present. Can we accept the identities of people and interactions of futures as fluid, diverse and queer as well? Imagine "Speculation" sitting on your shoulder and whispering these questions in your ear while you work:

- When does the present end and the future start?

- What binaries, clear cut events and societal milestones have made their way into our designs? Can we think of more individual and fluid measures?

- What potential for new interactions would we open up if we engage in queering the norms they are currently built upon?

- Who do we include or exclude in our futures? What would we like to make possible for whom if we could in the present?

Example: "Homes for Life" [84] is a story of a woman who buys a smart home for her mother who lives with dementia, opening new areas of speculation, against a backdrop of highly conservative gender roles; e.g., technical expertise lies with a male engineer, and the protagonist's husband is responsible for the maintenance of the house. The stereotypical interactions sink into the background, enabling the reader to focus on the interactions with the house, but this story reinforces stereotypes about women and elderly people. With "Speculation" as a muse, could the story have been more inclusive while still bringing critique about smart home technologies to the forefront? Britta later wrote "Homes for Death" for their thesis [80], making a woman who has been diagnosed with dementia the protagonist of the story who is now in control of the house herself. It is up to the reader to decide whether this is a future vision or an alternate version of the present-maybe one we would like to see?

Potential \& Limitations: This representation is not unproblematic in its whiteness, Westerness and thinness. It is not a distinct answer to what speculation does look like and can look like, but one representation among many. It is one way to remind us that there are a multitude of futures and it is up to us which ones we tell. This approach is the most helpful when iterating your (future) vision, as it is a lens to engage critically with your own work. In the present this might signal to others whether there are spaces for them in the shared futures we develop and even open up futures that people had not thought possible for themselves.

\section{DISCUSSION}

The variety of ideas in these perspectives stems from our personal and cultural experiences, feminist attunement to multiple perspectives [36], and queer theory's persistent questioning of normative logics [78]. The diversity of our group, spanning several continents and languages, enabled us to explore "mash-ups" such as insha'Allah and ojalá, respectfully drawing inspiration. Our varied perspectives do not form a complete set and do not offer coherence. They do not all agree; we as authors do not all completely agree. Different readers may be drawn to different perspectives. Our un-manifesto embraces these contradictions and offers these perspectives to inspire more plural approaches, encouraging others to create their own perspectives for design futuring.

We reflect on how our positionalities shaped each perspective and the target audiences we imagined for them. Amy works in the context of fashion design, a context historically excluded from the cultures of design research. When utilizing Parallel Presents in a workshop setting, she encourages participants to take bold leaps to imagine how fashion might be otherwise, countering this disciplinary marginalization. Sumita researches inclusion, empowerment, and accessibility for underserved children [86, 89, 90]; " $I$ Am Time" brings in her own cultural conceptions of time and seeks to empower more diverse participants, such as children, to engage in design futuring. Rocío comes from a fine arts background and teaches design to arts, design and technology students; Epithelial Metaphors moves away from technical and logical thinking toward encouraging forms of meaning-making from the Arts and Humanities. As a design researcher, Noura created the Uncertainties Cone to playfully poke at academic egotism. Britta includes speculation in her practice and her work with students in Germany and the UK and imagines it can be done better; Meet (with) "Speculation" invites practitioners to dialogue with their own practice to help them expand it. Our perspectives come from who we are and what we do, seeking to invite more diverse participation in design futuring. Shaped by varied positionalities and audiences, our un-manifesto offers polyvocality on not only who is futuring, but also why we are futuring. Each perspective may be differently poised to serve different goals such as decentering techno-innovation or rationality, reaching underserved children, providing a gentle ego check for experienced practitioners, or prompting more reflexive practice.

Many of our perspectives suggest alternative framings of time. Meet (with) "Speculation" reframes present/future as nonbinary, describing the future less as a space one arrives at, but rather a state inextricably linked with the present. "I Am Time" relates the present and future in cyclical time. Epithelial Metaphors considers present and future as merely two components amidst a flat hierarchy of cells. Parallel Presents turns time around, imagining possible histories for alternative presents. The Uncertainties Cone turns the cone backwards into a peephole and upside down into a dunce hat. These reframings of time may help sidestep deeply ingrained perceptions of the future such as the "space-age" aesthetic exemplified by 2001: A Space Odyssey, now over 50 years old [111]. Many design futuring projects embed a similarly pervasive, though less visually apparent, assumption of progress. From this mindset, technologies are set to develop into ever more corners of our lives and will come to fully permeate the human experience. If this assumption is not acknowledged and challenged, then design futuring can only question what kind of technological progress we want, rather than the more fundamental question of whether continued technological progress is desirable [48].

Our perspectives also reframe agency away from individualism. "I Am Time" attends to aspirational [56, 86, 99] and spiritual transformations and interdependencies of many timescales and cycles of change. The Uncertainties Cone critiques designerly agency and emphasizes uncertainty and humility. As a design tactic, the Uncertainties Cone resonates with recent calls in HCI to embrace uncertainty $[2,91]$ as generative for "exploring multiple possible future worlds" (p.3) [91]. It may also help attend to Akama and Light's punctuation, "a consciousness of working with immersing in the flow, gaps, and rhythms of change" (p. 19) [1]. Foregrounding the potentially overwhelming influence of external factors, the exercise holds space for failure and letting go [44], while highlighting dependencies may invite fairer citational practices [55]. Epithelial Metaphors also foregrounds interdependency of many 
factors as organically growing cells. Its biological metaphor is a wink to Guattari's ecosophical approach of diverse ideas to address ecological crises [34]. Embracing chaos, Humanities, and creativity encourages a shift in approach, opening up new approaches for professional designers, and also widening the circle of who can design and how.

Through combining personal experience, theory, and pop culture; suggesting alternative framings of time; sidestepping ingrained imaginaries of techno-progress; acknowledging uncertainty; inviting artistic epithelial metaphors; and attending to cyclical transformations, these perspectives offer a wide and inconclusive variety of approaches to design futuring-an unresolved plurality. By sharing our own partial, situated perspectives for design futuring, we hope to invite more diversity on who gets to future, and how they choose to do it.

\section{CONCLUSIONS}

Design futuring needs greater plurality. After outlining embedded assumptions of the Futures Cone as a point of departure, through our process reflecting on our own varied disciplinary and cultural backgrounds, we offer several perspectives for design futuring that draw from our own positionalities. We discuss how these perspectives open alternative approaches to design futuring by reframing past, present, and future, thinking outside prevalent notions of technological progress, and foregrounding interdependent, relational agencies over individualism. By offering these perspectives, we hope to invite and encourage others' perspectives to continue to broaden and diversify approaches to design futuring.

\section{ACKNOWLEDGMENTS}

This research is connected to the GenZ project, a strategic profiling project in human sciences at the University of Oulu. The project is supported by the Academy of Finland (Grant \#318930 and Grant \#324685, Make-a-Difference project) and the University of Oulu. We would also like to thank reviewers for their thoughtful commentary.

\section{REFERENCES}

[1] Akama, Y. and Light, A. 2020. Readiness for contingency: punctuation, poise, and co-design. CoDesign. 16, 1 (Jan. 2020), 17-28. DOI: https://doi.org/10.1080/ 15710882.2020.1722177

[2] Akama, Y., Pink, S. and Fergusson, A. 2015. Design + Ethnography + Futures: Surrendering in Uncertainty. Proceedings of the 33rd Annual ACM Conference Extended Abstracts on Human Factors in Computing Systems - CHI EA '15 (Seoul, Republic of Korea, 2015), 531-542.

[3] Arora, P. 2019. The next billion users: digital life beyond the West. Harvard University Press.

[4] Asad, M. 2019. Prefigurative Design as a Method for Research Justice. Proceedings of the ACM on Human-Computer Interaction. 3, CSCW (Nov. 2019), 1-18. DOI: https://doi.org/10.1145/3359302

[5] Asad, M. 2018. Prefigurative Design as an Alternative Approach to Civic Engagement. Companion of the 2018 ACM Conference on Computer Supported Cooperative Work and Social Computing (Jersey City NJ USA, Oct. 2018), 97-100.

[6] Auger, J. 2013. Speculative design: crafting the speculation. Digital Creativity. 24, 1 (Mar. 2013), 11-35. DOI: https://doi.org/10.1080/14626268.2013.767276

[7] Avellan, T., Sharma, S. and Turunen, M. 2020. AI for all: defining the what, why, and how of inclusive AI. Proceedings of the 23rd International Conference on Academic Mindtrek (Tampere Finland, Jan. 2020), 142-144.

[8] Bardzell, J. and Bardzell, S. 2016. Humanistic HCI. Interactions. 23, 2 (Feb. 2016), 20-29. DOI: https://doi.org/10.1145/2888576.

[9] Bardzell, S. 2010. Feminist HCI: Taking Stock and Outlining an Agenda for Design. Proceedings of the SIGCHI Conference on Human Factors in Computing Systems (New York, NY, USA, 2010), 1301-1310.

[10] Bardzell, S. and Bardzell, J. 2011. Towards a feminist HCI methodology: social science, feminism, and HCI. Proceedings of the SIGCHI Conference on Human
Factors in Computing Systems (New York, NY, USA, May 2011), 675-684.

[11] Bendor, R., Eriksson, E. and Pargman, D. 2021. Looking backward to the future: On past-facing approaches to futuring. Futures. 125, (Jan. 2021), 102666. DOI: https://doi.org/10.1016/j.futures.2020.102666

[12] Birkerts, S. 2008. Clarity and Obscurity in Poetry. Academy of American Poets.

[13] Blackman, M. 2001. Noughts \& Crosses. Penguin Books.

[14] Caughill, P. 2017. The SPCA has removed its controversial security robot. Futurism.

[15] Chatterton, T. and Newmarch, G. 2017. The future is already here: it's just not very evenly distributed. Interactions. 24,2 (Feb. 2017), 42-45. DOI: https: //doi.org/10.1145/3041215

[16] Cornish, E. 2005. Futuring: the exploration of the future. World Future Society.

[17] Costanza-Chock, S. 2020. Design justice: community-led practices to build the worlds we need. The MIT Press.

[18] Coulton, P. 2015. Speculative Game Design Manifesto at the Computer Arts Society.

[19] Coulton, P., Lindley, J., Sturdee, M. and Stead, M. 2017. Design Fiction as World Building. Proceedings of the 3nd Biennial Research Through Design Conference (2017).

[20] Dator, J. 2009. Alternative Futures at the Manoa School. Fournal of Futures Studies. 14, 2 (2009), 1-18.

[21] Devendorf, L., Andersen, K., Rosner, D.K., Wakkary, R. and Pierce, J. 2019. From HCI to HCI-Amusement: Strategies for Engaging what New Technology Makes Old. Proceedings of the 2019 CHI Conference on Human Factors in Computing Systems - CHI '19 (Glasgow, Scotland Uk, 2019), 1-12.

[22] Dick, P.K. 1962. The Man in the High Castle. G. P. Putnam's Sons.

[23] Dombrowski, L., Harmon, E. and Fox, S. 2016. Social Justice-Oriented Interaction Design: Outlining Key Design Strategies and Commitments. Proceedings of the 2016 ACM Conference on Designing Interactive Systems (New York, NY, USA, 2016), 656-671.

[24] Dunne, A. and Raby, F. 2013. Speculative everything: design, fiction, and social dreaming. The MIT Press.

[25] Escobar, A. 2018. Designs for the pluriverse: radical interdependence, autonomy, and the making of worlds. Duke University Press.

[26] Fatás, R. et al. 2020. Beyond Extractivism: Probing into Environmental Realities for Technological Speculations. Medium.

[27] Franz, M.-L. von 1980. On divination and synchronicity: the psychology of meaningful chance. Inner City Books.

[28] Gaver, W.W., Beaver, J. and Benford, S. 2003. Ambiguity As a Resource for Design. Proceedings of the SIGCHI Conference on Human Factors in Computing Systems (New York, NY, USA, 2003), 233-240.

[29] Geerts, E. and van der Tuin, I. 2016. Diffraction \& Reading Diffractively. New Materialism. 27 (2016)

[30] Glissant, É. 1997. For Opacity. Poetics of Relation. The University of Michigan Press. 189-194.

[31] Gohd, C. 2017. In a dystopian move, the SPCA is using a robot to scare off homeless people. Futurism.

[32] Grevatt, M. 2020. Biggest strike in world history: 250 million Indian workers. Workers World.

[33] Grimpe, B., Stahl, B.C., Ten Holter, C., Inglesant, P., Eden, G., Patel, M. and Jirotka, M. 2020. From collaborative to institutional reflexivity: Calibrating responsibility in the funding process. Science and Public Policy. (Oct. 2020), scaa038. DOI: https://doi.org/10.1093/scipol/scaa038

[34] Guattari, F. 2005. The three ecologies. Continuum.

[35] Hanna, J., Ashby, S., Matos, S., Faria, A. and Rodrigues, R. 2019. Dissent by Design: A Manifesto for CHI Manifestos. Extended Abstracts of the 2019 CHI Conference on Human Factors in Computing Systems (New York, NY, USA, May 2019), $1-10$.

[36] Haraway, D. 1988. Situated Knowledges: The Science Question in Feminism and the Privilege of Partial Perspectives. Feminist Studies. (1988), 575-599.

[37] Harren, N. 2016. Fluxus and the Transitional Commodity. Art Fournal. 75, 1 (Jan. 2016), 44-69. DOI: https://doi.org/10.1080/00043249.2016.1171540.

[38] Harren, N. 2015. The Crux of Fluxus: Intermedia, Rear-guard. Living Collections Catalogue. 2, 1 (2015).

[39] Having many rounds of conversations recently confirming the validity of the Many Worlds Future Cone from our previous research https://t.co/8KDOTG4Xlc: 2020. https://twitter.com/ushi_/status/1334494675844149250. Accessed: 2020-1207.

[40] Helgason, I., Smyth, M., Encinas, E. and Mitrović, I. 2020. Speculative and Critical Design in Education: Practice and Perspectives. Companion Publication of the 2020 ACM Designing Interactive Systems Conference (Eindhoven Netherlands, Jul. 2020), 385-388.

[41] Higgins, D. 2018. Intermedia, Fluxus and the Something Else Press: selected writings by Dick Higgins. siglio.

[42] Higgins, H. 2002. Fluxus experience. University of California Press.

[43] Holbert, N., Dando, M. and Correa, I. 2020. Afrofuturism as critical constructionist design: building futures from the past and present. Learning, Media and 
Technology. 45, 4 (Oct. 2020), 328-344. DOI: https://doi.org/10.1080/17439884. 2020.1754237

[44] Howell, N., Desjardins, A. and Fox, S. 2020. Cracks in the Success Narrative: Rethinking Failure in Design Research Through a Retrospective Trioethnography. Currently under review, preprint cited with permission of the authors. (2020).

[45] Howell, N., Niemeyer, G. and Ryokai, K. 2019. Life-Affirming Biosensing in Public: Sounding Heartbeats on a Red Bench. Human Factors in Computing Systems (2019).

[46] Irani, L., Vertesi, J., Dourish, P., Philip, K. and Grinter, R.E. 2010. Postcolonial computing: a lens on design and development. (Apr. 2010), 1311-1320.

[47] Jenkins, T., Vallgårda, A., Boer, L., Homewood, S. and Almeida, T. 2019. Careful Devices. Proceedings of the Halfway to the Future Symposium 2019 on - HTTF 2019 (Nottingham, United Kingdom, 2019), 1-5.

[48] Jirotka, M., Grimpe, B., Stahl, B., Eden, G. and Hartswood, M. 2017. Responsible research and innovation in the digital age. Communications of the ACM. 60, 5 (Apr. 2017), 62-68. DOI: https://doi.org/10.1145/3064940

[49] Kaufman, S.B. 2014. The Controlled Chaos of Creativity. Scientific American Blog Network.

[50] King, A. and Cronin, A. 2016. Queer Methods and Queer Practices: Re-examining the Identities of Older Lesbian, Gay, Bisexual Adults. Queer Methods and Methodologies: Intersecting Queer Theories and Social Science Research. C.J. Nash and K. Browne, eds. Routledge.

[51] Kotilainen, S., Okkonen, J., Spurava, G., Sejer Iversen, O., Iivari, N., Kinnula, M. and Sharma, S. 2020. Researchers' Toolbox for the Future: Empowering Children to Shape Their Future. Proceedings of the 11th Nordic Conference on HumanComputer Interaction: Shaping Experiences, Shaping Society (Tallinn Estonia, Oct. 2020), 1-3.

[52] Kozubaev, S. and DiSalvo, C. 2020. The Future of Public Libraries as Convivial Spaces: A Design Fiction. Companion of the 2020 ACM International Conference on Supporting Group Work (Sanibel Island Florida USA, Jan. 2020), 83-90.

[53] Kozubaev, S., Elsden, C., Howell, N., Søndergaard, M.L.J., Merrill, N., Schulte, B. and Wong, R.Y. 2020. Expanding Modes of Reflection in Design Futuring. Proceedings of the 2020 CHI Conference on Human Factors in Computing Systems (Honolulu HI USA, Apr. 2020), 1-15.

[54] Kuchay, B. 'Bharat Bandh': Indian farmers launch strike to press for demands. Al fazeera.

[55] Kumar, N. and Karusala, N. 2020. Braving Citational Justice Within HCI. Medium

[56] Kumar, N., Wong-Villacres, M., Karusala, N., Vishwanath, A., Kumar, A. and Ismail, A. 2019. Aspirations-based Design. Proceedings of the Tenth International Conference on Information and Communication Technologies and Development (New York, NY, USA, 2019), 2:1-2:11.

[57] Lindley, J., Sharma, D. and Potts, R. 2015. Operationalizing Design Fiction with Anticipatory Ethnography. (2015), 58-71.

[58] Linehan, C. and Kirman, B. 2014. Never mind the bollocks, i wanna be anarCHI: a manifesto for punk HCI. CHI '14 Extended Abstracts on Human Factors in Computing Systems (New York, NY, USA, Apr. 2014), 741-748.

[59] Mancini, C. 2011. Animal-computer interaction: a manifesto. Interactions. 18, 4 (Jul. 2011), 69-73. DOI: https://doi.org/10.1145/1978822.1978836

[60] Mazé, R. 2019. Politics of Designing Visions of the Future. fournal of Futures Studies. 23, 3 (Mar. 2019). DOI: https://doi.org/10.6531/JFS.201903_23(3).0003.

[61] Mehtonen, P. 1996. Obscurity as a Linguistic Device: Introductory and Historical Notes. Danish Yearbook of Philosophy. 31, (1996), 157-168.

[62] Moeggenberg, Z.C. and Walton, R. 2019. How queer theory can inform design thinking pedagogy. Proceedings of the 37th ACM International Conference on the Design of Communication (Portland Oregon, Oct. 2019), 1-9.

[63] Noortman, R., Schulte, B.F., Marshall, P., Bakker, S. and Cox, A.L. 2019. HawkEye - Deploying a Design Fiction Probe. Proceedings of the 2019 CHI Conference on Human Factors in Computing Systems (New York, NY, USA, 2019), 422:1-422:14.

[64] de O. Martins, L.P. and de Oliveira, P.J.S.V. 2016. Breaking the cycle of Macondo: design and decolonial futures. XRDS: Crossroads, The ACM Magazine for Students. 22, 4 (Jun. 2016), 28-32. DOI: https://doi.org/10.1145/2930880

[65] Oakland Privacy: https://oaklandprivacy.org/. Accessed: 2020-12-09.

[66] Oliveros, P. 2005. Deep listening: a composer's sound practice. iUniverse.

[67] Oliveros, P. 1971. Sonic Meditations. Smith Publications American Music.

[68] Ono, Y. 1971. Grapefruit. Sphere.

[69] Pal, J., Lakshmanan, M. and Toyama, K. 2009. "My child will be respected": Parental perspectives on computers and education in Rural India. Information Systems Frontiers. 11, 2 (Apr. 2009), 129-144. DOI: https://doi.org/10.1007/s10796009-9172-1

[70] Pattnaik, I., Lahiri-Dutt, K., Lockie, S. and Pritchard, B. 2018. The feminization of agriculture or the feminization of agrarian distress? Tracking the trajectory of women in agriculture in India. Journal of the Asia Pacific Economy. 23, 1 (Jan 2018), 138-155. DOI: https://doi.org/10.1080/13547860.2017.1394569

[71] Philip, K., Irani, L. and Dourish, P. 2012. Postcolonial Computing: A Tactical Survey. Science, Technology, \& Human Values. 37, 1 (Jan. 2012), 3-29. DOI: https //doi.org/10.1177/0162243910389594

[72] Priest, C. 2011. Diana Wynne Jones obituary. the Guardian. commissions/privacy-advisory-board. Accessed: 2020-12-09.
[74] Puig de la Bellacasa, M. 2015. Making time for soil: Technoscientific futurity and the pace of care. Social Studies of Science. 45, 5 (Oct. 2015), 691-716. DOI: https://doi.org/10.1177/0306312715599851

[75] Rebola, C.B. and Eden, G. 2017. Remote robotic disability: are we ready for robots? Interactions. 24, 3 (Apr. 2017), 48-53. DOI: https://doi.org/10.1145/ 3064649

[76] Respecting our Relations: Dori Tunstall on Decolonizing Design: 2019. https://medium.com/@JacobsDesignCal/respecting-our-relations-doritunstall-on-decolonizing-design-d894df4c2ed2. Accessed: 2020-12-12.

[77] Robinson, M. Robots are being used to deter homeless people from setting up camp in San Francisco. Business Insider.

[78] Rooke, A. 2009. Queer in the Field: On Emotions, Temporality, and Performativity in Ethnography. Journal of Lesbian Studies. 13, 2 (Apr. 2009), 149-160. DOI: https://doi.org/10.1080/10894160802695338

[79] Sanders, I. 2020. 'Possible Futures.' Discuss. From this morning's beach walk. https://t.co/zW03NNYEnC.@IanSanders.

[80] Schulte, B.F. 2020. Homes for Life \& Other Stories The Use and Evaluation of Design Fiction as a Means to Understand Sensitive Settings: a Case Study of Exploring Technologies for Dementia Care. University College London.

[81] Schulte, B.F. 2016. Using design fiction to reflect on autonomy in smart technology for people living with dementia. Proceedings of the 2016 ACM International Foint Conference on Pervasive and Ubiquitous Computing: Adjunct (Heidelberg Germany, Sep. 2016), 1110-1113.

[82] Schulte, B.F. Zine: Dementia \& Privacy.

[83] Schulte, B.F., Lechelt, Z. and Singh, A. 2018. Giving up Control - A Speculative Air Pollution Mask to Reflect on Autonomy and Technology Design. Proceedings of the 19th International ACM SIGACCESS Conference on Computers and Accessibility - DIS '18 (Hong Kong, China, 2018), 177-181.

[84] Schulte, B.F., Marshall, P. and Cox, A.L. 2016. Homes For Life: A Design Fiction Probe. Proceedings of the 9th Nordic Conference on Human-Computer Interaction - NordiCHI '16 (Gothenburg, Sweden, 2016), 1-10.

[85] Selkirk, K., Selin, C. and Felt, U. 2018. A Festival of Futures: Recognizing and Reckoning Temporal Complexity in Foresight. Handbook of Anticipation: Theoretical and Applied Aspects of the Use of Future in Decision Making. R. Poli, ed. Springer International Publishing. 1-23.

[86] Sharma, S., Avellan, T., Linna, J., Achary, K., Turunen, M., Hakulinen, J. and Varkey, B. 2020. Socio-Technical Aspirations for Children with Special Needs: A Study in Two Locations - India and Finland. ACM Transactions on Accessible Computing. 13, 3 (Aug. 2020), 1-27. DOI: https://doi.org/10.1145/3396076

[87] Sharma, S., Kallioniemi, P., Heimonen, T., Hakulinen, J., Turunen, M. and Keskinen, T. 2018. Overcoming socio-technical challenges for cross-cultural collaborative applications. Proceedings of the 17th ACM Conference on Interaction Design and Children (Trondheim Norway, Jun. 2018), 325-336.

[88] Sharma, S., Niculescu, A.I., Eden, G., Sim, G., Toprani, D., Thankachan, B., Read, J.C., Turunen, M. and Kallioniemi, P. 2018. Engaging different worlds, one field trip at a time. Interactions. 25, 3 (Apr. 2018), 46-51. DOI: https://doi.org/10.1145/ 3197573

[89] Sharma, S., Srivastava, S., Achary, K., Varkey, B., Heimonen, T., Hakulinen, J., Turunen, M. and Rajput, N. 2016. Gesture-based Interaction for Individuals with Developmental Disabilities in India. Proceedings of the 18th International ACM SIGACCESS Conference on Computers and Accessibility (Reno Nevada USA, Oct. 2016), 61-70.

[90] Sharma, S., Srivastava, S., Achary, K., Varkey, B., Heimonen, T., Hakulinen, J.S., Turunen, M. and Rajput, N. 2016. Promoting Joint Attention with Computer Supported Collaboration in Children with Autism. Proceedings of the 19th ACM Conference on Computer-Supported Cooperative Work \& Social Computing-CSCW '16 (San Francisco, California, USA, 2016), 1558-1569.

[91] Soden, R., Devendorf, L., Wong, R.Y., Chilton, L.B., Light, A. and Akama, Y. 2020. Embracing Uncertainty in HCI. Extended Abstracts of the 2020 CHI Conference on Human Factors in Computing Systems (Honolulu HI USA, Apr. 2020), 1-8.

[92] Søndergaard, M.L.J. and Hansen, L.K. 2018. Intimate Futures: Staying with the Trouble of Digital Personal Assistants Through Design Fiction. Proceedings of the 2018 Designing Interactive Systems Conference (New York, NY, USA, 2018), 869-880.

[93] Spiel, K., Keyes, O., Walker, A.M., DeVito, M.A., Birnholtz, J., Brulé, E., Light, A., Barlas, P., Hardy, J., Ahmed, A., Rode, J.A., Brubaker, J.R. and Kannabiran, G. 2019. Queer(ing) HCI: Moving Forward in Theory and Practice. Extended Abstracts of the 2019 CHI Conference on Human Factors in Computing Systems (Glasgow Scotland Uk, May 2019), 1-4.

[94] State Facial Recognition Policy: https://epic.org/state-policy/facialrecognition/. Accessed: 2020-12-09.

[95] Tharp, B.M. and Tharp, S.M. 2018. Discursive design: critical, speculative, and alternative things. The MIT Press.

[96] The Futures Cone, use and history: 2017. https://thevoroscope.com/2017/02/24/ the-futures-cone-use-and-history/. Accessed: 2019-08-02.

[97] The History of the Lorgnette: https://www.mimimatthews.com/2015/09/20/thehistory-of-the-lorgnette/. Accessed: 2020-12-09. 
[98] The Thing From The Future by the Situation Lab: http://situationlab.org/project/ the-thing-from-the-future/. Accessed: 2020-12-02.

[99] Toyama, K. 2017. Design, Needs, and Aspirations in International Development Information and Communication Technologies for Development. J. Choudrie, M.S. Islam, F. Wahid, J.M. Bass, and J.E. Priyatma, eds. Springer International Publishing. 24-32.

[100] Tran O'Leary, J., Zewde, S., Mankoff, J. and Rosner, D.K. 2019. Who Gets to Future?: Race, Representation, and Design Methods in Africatown. Proceedings of the 2019 CHI Conference on Human Factors in Computing Systems (New York, NY, USA, 2019), 561:1-561:13.

[101] Tunstall, E.D. 2019. Berkeley Talks transcript: Design anthropologist Dori Tunstall on decolonizing design.

[102] Tunstall, E.D. 2013. Decolonizing Design Innovation: Design Anthropology, Critical Anthropology, and Indigenous Knowledge. Design anthropology: theory and practice. W. Gunn, T. Otto, and R.C. Smith, eds. Bloomsbury.

[103] Tunstall, E.D. 2019. Respecting our Relations: Dori Tunstall on Decolonizing Design.

[104] Twigger Holroyd, A. 2019. Designing fashion fictions: speculative scenarios for sustainable fashion worlds. The Design After: Cumulus Conference proceedings, Bogota 2019. Universidad de los Andes. 341-351.

[105] Twigger Holroyd, A. 2018. Reknit Revolution: Knitwear Design for the Domestic Circular Economy. Fournal of Textile Design Research and Practice. 6, 1 (Jan. 2018), 89-111. DOI: https://doi.org/10.1080/20511787.2018.1452141
[106] Twigger Holroyd, A., Cassidy, T., Evans, M. and Walker, S. 2017. Wrestling with Tradition: Revitalizing the Orkney Chair and Other Culturally Significant Crafts. Design and Culture. 9, 3 (Sep. 2017), 283-299. DOI: https://doi.org/10. 1080/17547075.2017.1370310

[107] Voros, J. 2017. Big History and Anticipation. Handbook of Anticipation. R. Poli, ed. Springer International Publishing. 1-40.

[108] Walker, S., Evans, M., Cassidy, T., Jung, J. and Holroyd, A.T. eds. 2018. Design roots: Culturally significant designs, product, and practices. Bloomsbury Academic, an imprint of Bloomsbury Publishing Plc.

[109] Wang, X. 2020. Blockchain chicken farm: and other stories of tech in China's countryside. Farrar, Straus and Giroux.

[110] Wong, R.Y. and Khovanskaya, V. 2018. Speculative Design in HCI: From Corporate Imaginations to Critical Orientations. New Directions in Third Wave Human-Computer Interaction: Volume 2 - Methodologies. Springer, Cham. 175202.

[111] 2020. 2001: A Space Odyssey (film). Wikipedia.

[112] Antonin Artaud: French author and actor. Encyclopedia Britannica

[113] 2020. Fluxus. Wikipedia.

[114] 2020. Mahabharat (1988 TV series). Wikipedia.

[115] 2020. Surrealism. Wikipedia.

[116] 2020. The Sandman (comic book). Wikipedia.

[117] 2020. Yuga Cycle. Wikipedia. 